九州霜会誌 $40(1): 216 \sim 228,1986$.

\title{
蒾肉乏トコンドリアの呼吸調節に関する研究
}

\author{
福岡曾科大学歯科保存学第 2 講座（指導：栢 豪洋教授）
}

原 賀 義 昭

昭和 60 年 12 月 23 日受付

\section{A Study on Respiratory Control of Mitochondrial \\ Preparation in Dog Gingiva \\ Yoshiaki Haraga}

\begin{abstract}
Department of Endodontics and Periodontics (Director: Prof. Hidehiro Kaya) Fukuoka Dental College, Fukuoka, Japan
\end{abstract}

Many authors have studied the gingival respiration with slice and homogenate to measure the respiration in Warburg respirometer flask. However, no study on the ability to respiratory control of gingiva has been reported. The author prepared the several mitochondrial fractions from gingiva and measured the mitochondrial respiration to obtain the fractions with ability to respiratory control.

The gingiva was excised from dogs during anesthesia and minced in cold. The minced gingiva was homogenized with Polytron for $0.5 \mathrm{~min} ., 1 \mathrm{~min}$., $1.5 \mathrm{~min} ., 2 \mathrm{~min}$., $5 \mathrm{~min}$. and $10 \mathrm{~min}$. separately. And then, the nucleus, mitochondrial and supernatant fractions were prepared by differential centrifugation method.

On the other hand, the minced gingiva was treated with $0.04 \%, 0.2 \%, 1 \%$ and $5 \%$ collagenase respectively and homogenized with Polytron for $1 \mathrm{~min}$.. Then, the nucleus, mitochondrial and supernatant fractions were prepared by centrifugation.

Relative specific activity of the succinate dehydrogenase was measured on each fraction. Furthermore, the respiration of the mitochondrial preparation was measured by using the oxygen electrode.

Results are:

1. In the mitochondrial fractions treated with Polytron for $0.5 \mathrm{~min}$. to $10 \mathrm{~min}$., the highest relative specific activity of the succinate dehydrogenase was observed in the treatment for 2 min..

2. The highest activity was present in the mitochondrial fraction treated with $1 \%$ collagenase in the course of digestions with $0.04 \%, 0.2 \%, 1 \%$ and $5 \%$ collagenase.

3. The respiratory control was observed in the mitochondrial preparations treated with $1 \%$ and $5 \%$ collagenase when the endogenous, succinate-stimulated and ADPstimulated respirations were measured.

4. The mitochondrial preparation treated with $1 \%$ collagenase had the highest ADP /O ratio and respiratory control rate in the present study.

Key words : Respiratory control/Gingival mitochondria/Oxygen electrode 


\section{緒}

\section{言}

ミトコンドリアの呼吸活性に関する研究は1913年 Warburg が細胞中に不溶性の呼吸能力のある顆粒があ るのを見出したのに始まり, Hogeboom (1948) ${ }^{1}{ }^{1}$, Schneider $(1948)^{2}$ らが $0.25 \mathrm{M} シ ョ$ 糖液の組織ホモジネ 一トを遠心分画してての顆粒を単離してからその基礎が 築かれ，それ以来著しく進歩し数多くの報告がなされて いる3-5!。

心筋は持続的で激しい筋肉運動を行っており，心筋之 トコンドリアの調製には肝組織の場合のように緩和な組 織破砕手段をとるわけにいかず,現在では，機械的に破砕 するポリトロンホモジナイザーによる方法と Bacillus subtilis 由来のナガーゼを用いるタンパク分解酵素消化 法を併用する調製方法が行われている6'。 また，酵母は 単細胞生物でそのミトコンドリアにおける呼吸系は高等 動物に似ており古くから研究されているが，その細胞壁 が強固なためミトコンドリアを分離することが出来なか った。從って，ての紐胞壁をタンパク分解醭素を使って 破壊する酵素法で調製が行われている7，8．

てうして調製されたミトコンドりアは呼忣基質や ADP を涯加することにより呼吸状態を変化させ, この 変化加ら Chance ら (1963) ${ }^{6)}$ の分類する各段階の酸素 消費量を求めることにより酸化的リン酸化の研究がなさ れている。

歯肉の呼吸活性については Glickman ら $(1950)^{10}$ が 蒾周外科手術時に得た柬肉をスライスして炎症歯肉酸素 消費量を測定している。それによると，曾肉次资症が存 在すると霜肉の酸素消費量は増加するが，細胞変性を併 うものは酸素消費量は減少したという報告をしており， その後, 川勝ら $(1958)^{111}$, 鍬型 $(1957)^{12)}$, 高田ら $\left.(1957)^{13}\right)$ らもとト正常歯肉, 歯肉炎, 歯周病やダイラン チン性雬肉炎についても検討し酸素消費量の変動を報告 している.呼吸基質の影蠁に関する研究は Lehninger (1964)14’木下（1959）15〉 らが蒾肉スライスにコハク 酸を添加して, 橉肉酸素消費量の増加を報告している。 しかし，それをさらに発展させた橉肉ホモジネートに関 する研究では, Person ら (1960) ${ }^{16)}$, Eichel ら (1957) 17)，木下(1959) 15) らが Warburg manometer いて呼吸活性を研究，菌肉ホモジートに呼吸基質を加 えると酸素消費量は增加するものの, 歯肉スライスに比 して酸素消費量が低いことに疑問を持ち始めた。歯肉木 モジネートにチトクローム C, NAD, FAD を添加する ととによって乎吸活性にいくぶん回復がみられることか
ら，彼等は歯肉をホモジートすることにより電子伝 達系阻止物質の遊離，チトクロームの破壊，“dilution effect”による補酵素の分散などの仮説をたて研究を行 ったが12，13，それらを考慮に入れても内在呼吸の著し い低下を説明出来乃他の因子は不明のままになってお り，ミトコンドリア細胞分画や呼吸活性に関する研究は まったく報告されていない。

そこで著者は本研究において，心笳のタンパク分解醉 素消化法と酵母の細胞壁に対するタンパク分解酵素法に 着眼し，コラーゲンに富む歯肉組織 ${ }^{18}{ }^{\prime}$ から らトコンド リアを調製するため雷肉コラーゲンをコラーゲン分解酵 素で消化する方法を用いてミトコンドリアを調製し，コ 八ク酸脱水素酵素と酸素消費量を指標として, 呼吸調節 を有する雨肉ミトコンドリアの調整方法を検索した.

\section{実験材料ならびに方法}

I. 歯肉ミンス状細片

実験材料として，雄性成犬の臨床的に正常とみなされ る上下顎曰䨑部煩側雪肉を，ペントバルビタール・ナト リウム麻酔下にて顎骨より採取した。採取した匊肉は $220 \mathrm{mM}$ mannitol, $70 \mathrm{mM}$ sucrose , $5 \mathrm{mM}$ MOPS ( $\mathrm{pH}$ 7.4）からなる溶液 ${ }^{19}$ 'にて洗浄しメスを用いミンス状細 片とした。

II .ポリトロンによる荬肉ホモジネートの調製

A ・ポリトロンホモジナイザーによる調製

上記のようにして得られたミンス状細片にあらかじめ 氷冷した 3 倍量の $53.9 \mathrm{mM}$ mannitol, $17.2 \mathrm{mM} \mathrm{su-}$ crose, $0.05 \mathrm{mM}$ EDTA, $1 \mathrm{~g} / 1$ BSA, $1.2 \mathrm{mM}$ MOPS （pH 7.4）汃らなる溶液 ${ }^{19}$ を加え, キネマチ力社製 RT 10-35 ポリトロンを用い水冷下でそれぞれ 0.5 分， 1 分， 1.5 分, 2 分, 5 分, 10 分間ホモジネートした（以後ポ リトロンホモジートと略す).

B . ポリトロンホモジネートとコラーゲン分解酵素に よる調製

氷冷したミンス状細片を $0.04 \%, 0.2 \%, 1 \%, 5 \%$ コラーゲン分解酵素を含む $20 \mathrm{ml}$ の Hanks の溶液（pH 7.4）に入れ $20^{\circ} \mathrm{C}, 20$ 分間インキュベーションしたのち, ポリトロンにて 1 分間ポリトロンホモジナイズした.コ ラーゲン分解酵素はつぎの操作の $4500 \times g$ で遠心除去 した。

III · 歯肉乏トコンドリアの調製

上記の方法で調製した歯肉ポリトロンホモジネートを $4500 \times g$ で10分間遠心し上清は上清 $\left(S_{1}\right)$ 画分とし, 沈 渣に $20 \mathrm{ml}$ の $100 \mathrm{mM} \mathrm{KCI}, 2 \mathrm{~g} / 1 \mathrm{BSA}, 50 \mathrm{mM}$ MOPS 
(pH 7.4）からなる溶液 ${ }^{19)}$ 在加えテフロンホモジナイ ザーにてホモジナイズした，つぎに，500×g で10分間 遠心しその沈椬を核画分とし，上清は $4500 \times g$ 亿て 10 分 間遠心を行い，乏トコンドリア画分と上清 $\left(\mathrm{S}_{2}\right)$ 画分に 分画した。

N . 酸素消費量と呼吸活性の測定

酸素消費量の測定にはガラス製で 2 重構造の特殊な容 器をもつユニオン技研社製酸素電極装置を使用した。こ の装置の反応容器はミトコンドリアと反応液をマグネチ ックスターラーにより攪拌し, 反応容器のまわりに $25^{\circ} \mathrm{C}$ の恒温水を循環させるととにより反応容器内を一定温度 に保ち酸素を消費させるように工夫してある，容器左有 上部にはガラス棒に白金電極と塩化銀電極を内蔵させそ の先端をセルロースでコーティングし，雨電極間に0.65 Vの電圧をかけ自動平衡記録計に電解電流值を記録さ せ酸素消費量を測定した。な抢， $2 \mathrm{mM}$ コ八ク酸や 100 $\mu \mathrm{M}$ adenosine 5-diphosphate (以下 ADP と略す) の添加は反応容器上部のキャピラリーよりマイクロシリ ンジを用いて行った（Fig． 3)。

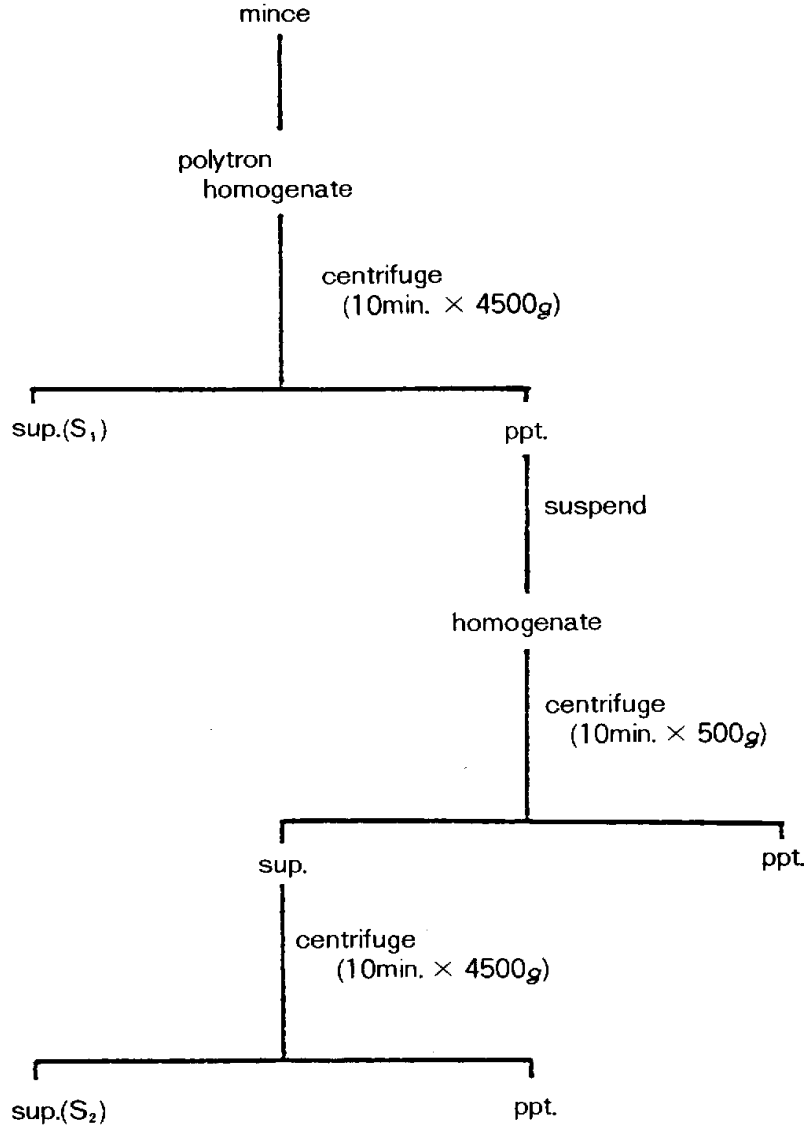

Fig. 1 Procedure for the preparation of mitochondrial fraction from dog gingiva (Polytron).

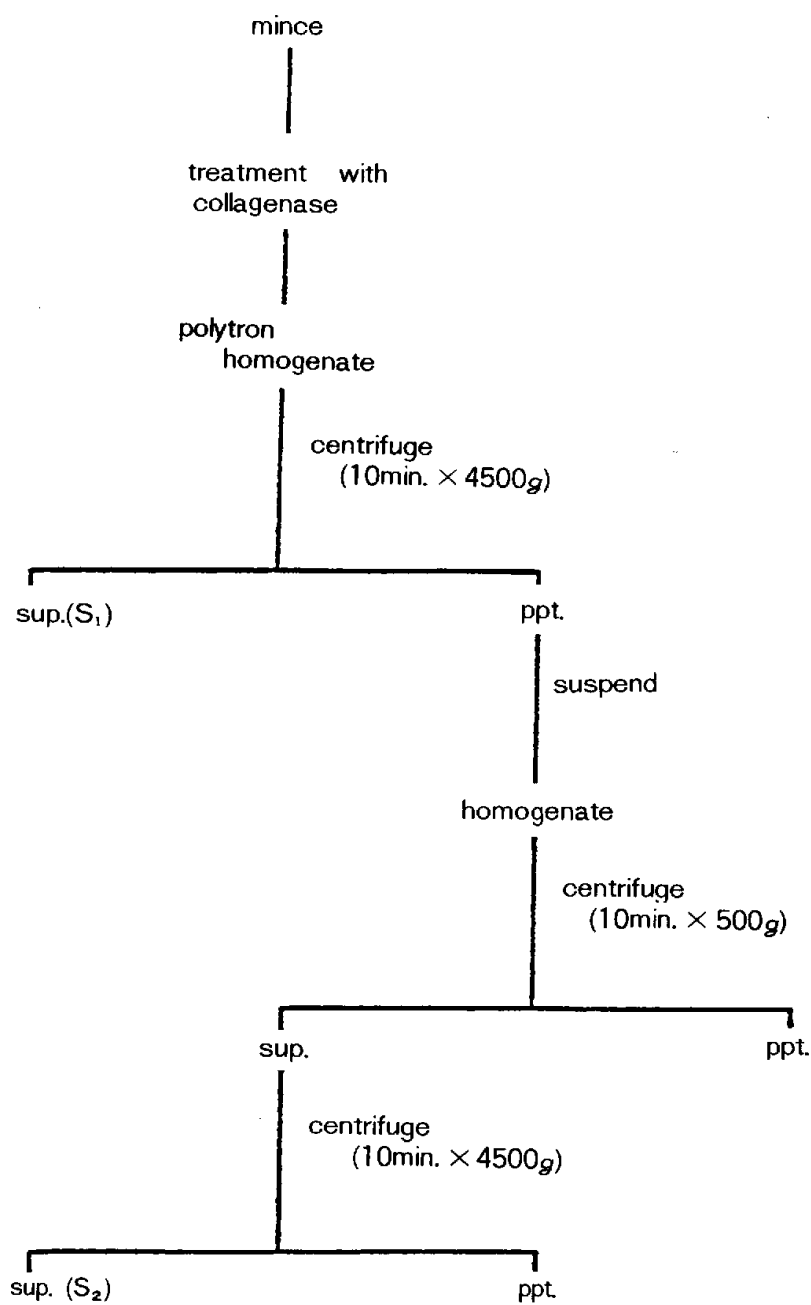

Fig. 2 Procedure for the preparation of mitochondrial fraction from dog gingiva (collagenase).

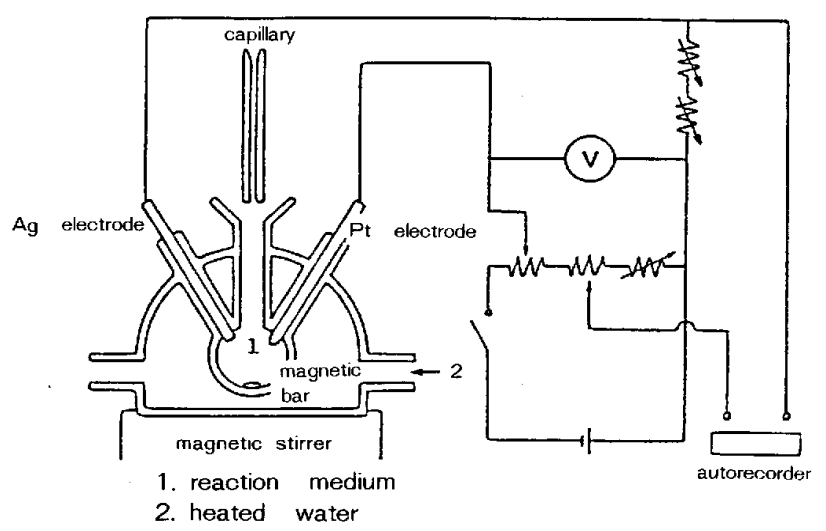

Fig. 3 Apparatus of oxygen electrode.

呼吸活性は Chance ら (1955) ${ }^{20}$ の state 1，2，3, 4 と分類して行い, state 4 が観察できたるトコンドリ ア画分については state 3 の酸素消費量も測定した. 酸素消費量は溶存酸素の減少を電解電流の減少として記 
録させ，電流值あたりの溶存酸素量は萩原 $(1965)^{21)}$ の 方法により求めた. ADP/O 比や呼吸調節率については Estabrook (1967) 22)の方法により求めた.

$\mathrm{V}$. 酵素活性とタンパク量の測定

A . コハク酸脱水素酵素活性

ミトコンドリアの指標酲素として一般的に用いられて いるコハク酸脱水素酵素はフェリシアン化カリの還元能 にて定量を行う Slater と Bonner の改良法23'老用い た. 測定は武料に $0.3 \mathrm{M} \mathrm{KCN}$ を加え, コハク酸脱水素 醉素以外の乎吸系を阻害したのち，0.4M コハク酸, 75 $\mu \mathrm{M} \mathrm{K} \mathbf{K}_{3} \mathrm{Fe}(\mathrm{CN})_{6}$ を加え, 日立社製 200-20 型分光光度 計にて吸光度 $455 \mathrm{~nm}$ で測定した。

B .タンパク量の測定

タンパク量の測定は Lowry ら (1951) の方法 ${ }^{24}$ に従 った・標準タンパクとして bovine serum albumin を 使用した。

VI. 試薬

コラーゲン分解酵䒱（タイプ I ）， ADP は Sigma Chemical 社製, Hanks の溶液は阪大微生物陃研究会, コハク酸 2 ナトリウム, MOPS, EDTA は半井化学薬 品社製を使用した。

\section{結 果}

I . ポりトロンホモジネート操作時間とコハク酸脱水 素酵秦の比活性

ポリトロンを用いてイヌ雪肉ミンス状細片を0.5分, 1 分, 1.5 分, 2 分, 5 分と 10 分間ホモジネートし調製 した核画分, ミトコンドリア画分, 上清 $\left(\mathbf{S}_{2}\right)$ 画分のコ 八ク酸脱水素酵素の比活性の平均值と標準偏差を Table 1 に示した。コハク酸脱水素醳素の比活性と各画分の夕 ンパク量の関係を表わす相対比活性を Figs. $4 \sim 9$ に示 した。

ポリトロン操作時間 0.5 分では操作時間 1 分以上に比 べて核画分のコハク酸脱水素䤃素の比活性は最も高く，

上清 $\left(\mathrm{S}_{2}\right)$ 画分の比活性は最も低い。また操作時間 0.5 分と 1 分では核画分の相対比活性がともに大きく，曾肉 組織の破砕が十分ではないことを示唆している.

核画分の比活性は操作時間が長くなるとともに減少傾 向を示し, 上清 $\left(\mathrm{S}_{2}\right)$ 画分の比活性は操作時間が 2 分で 最も低くなり，さらに操作時閒を増すと比活性も増加し ている. 相対比活性は操作時間の增加とともに核画分で は減少傾向を示すが，ミトコンドリア画分の比活性は操 作時間が増加するにしたがって高くなる. 操作時間 2 分 で最大を示し, 操作時間を 5 分, 10 分と延長するとミト
Table 1 Specific activity of succinate dehydrogenase in subcellular fractions prepared with Polytron homogenate.

\begin{tabular}{c|c|c|c}
\hline $\begin{array}{c}\text { time of } \\
\begin{array}{c}\text { Polytron } \\
\text { homogenate } \\
\text { (min.) }\end{array}\end{array}$ & $\begin{array}{c}\text { nuclear } \\
\text { fraction }\end{array}$ & $\begin{array}{l}\text { mitochon. } \\
\text { fraction }\end{array}$ & $\begin{array}{c}\text { supernatant } \\
\left(\mathrm{S}_{2}\right)\end{array}$ \\
\hline 0.5 & $3.21 \pm 1.02$ & $1.53 \pm 0.43$ & $0.38 \pm 0.06$ \\
1 & $1.69 \pm 0.66$ & $1.39 \pm 0.47$ & $0.56 \pm 0.14$ \\
1.5 & $1.38 \pm 0.46$ & $2.48 \pm 0.42$ & $0.69 \pm 0.21$ \\
2 & $1.85 \pm 0.61$ & $5.96 \pm 1.19$ & $0.41 \pm 0.09$ \\
5 & $0.99 \pm 0.56$ & $4.65 \pm 1.30$ & $0.83 \pm 0.11$ \\
10 & $0.80 \pm 0.32$ & $2.03 \pm 0.64$ & $0.95 \pm 0.23$ \\
\hline & & $\mu \mathrm{mol} / \mathrm{min} . / \mathrm{mg}$ protein
\end{tabular}

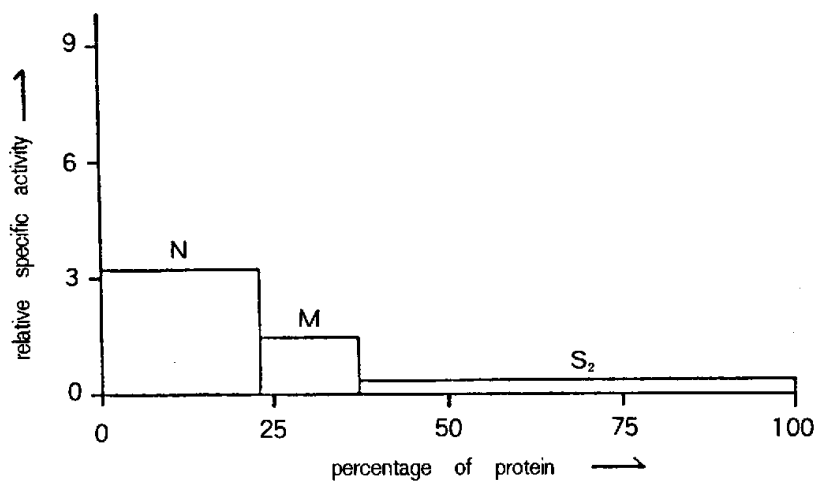

Fig. 4 Relative specific activity of succinate dehydrogenase in subcellular fractions prepared by Polytron treatment for $0.5 \mathrm{~min}$.

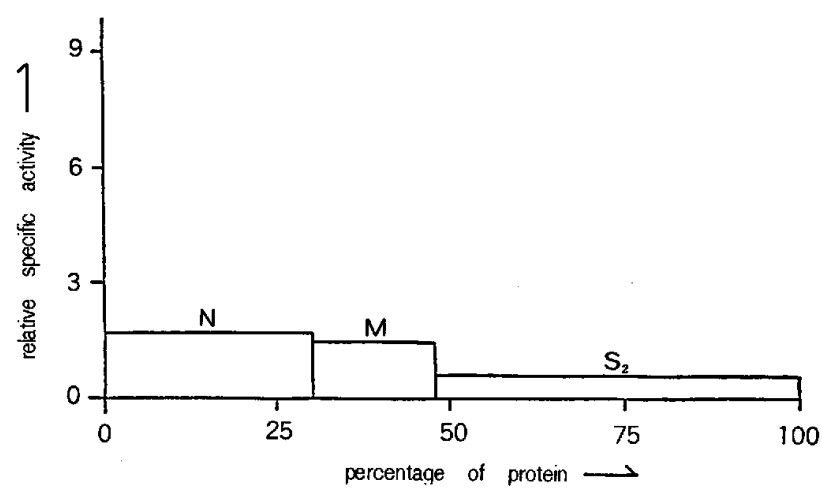

Fig. 5 Relative specific activity of succinate dehydrogenase in subcellular fractions prepared by Polytron treatment for $1 \mathrm{~min}$. 


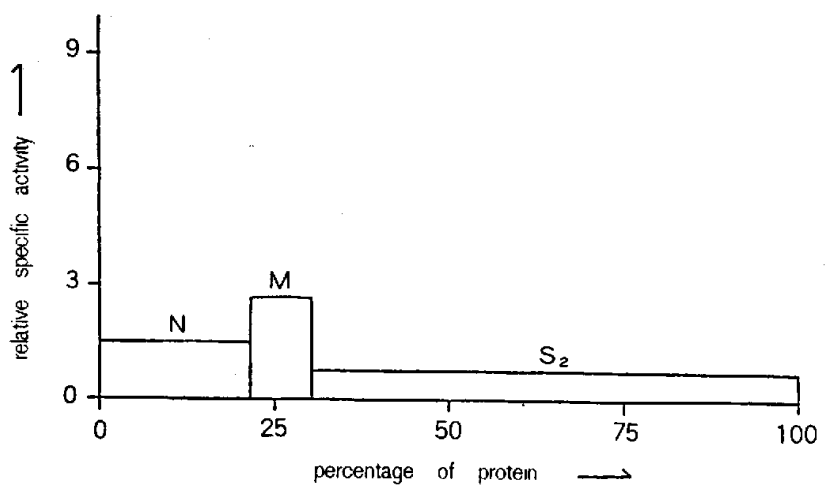

Fig. 6 Relative specific activity of succinate dehydrogenase in subcellular fractions prepared by Polytron treatment for $1.5 \mathrm{~min}$.

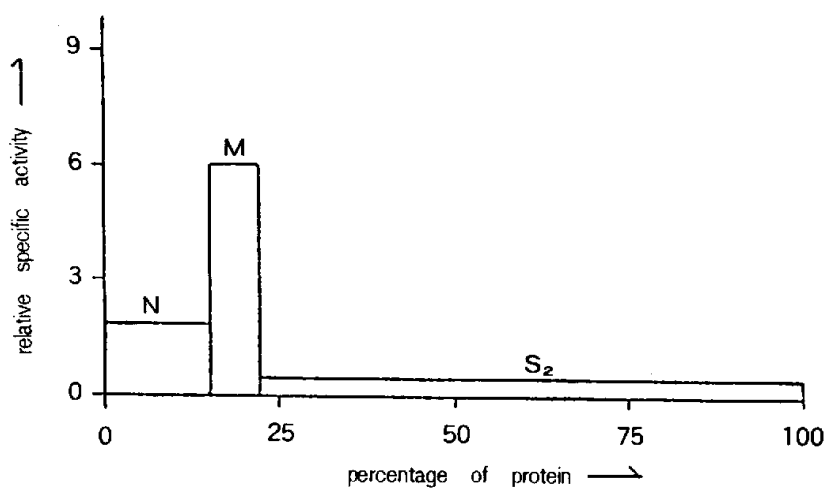

Fig. 7 Relative specific activity of succinate dehydrogenase in subcellular fractions prepared by Polytron treatment for $2 \mathrm{~min}$.

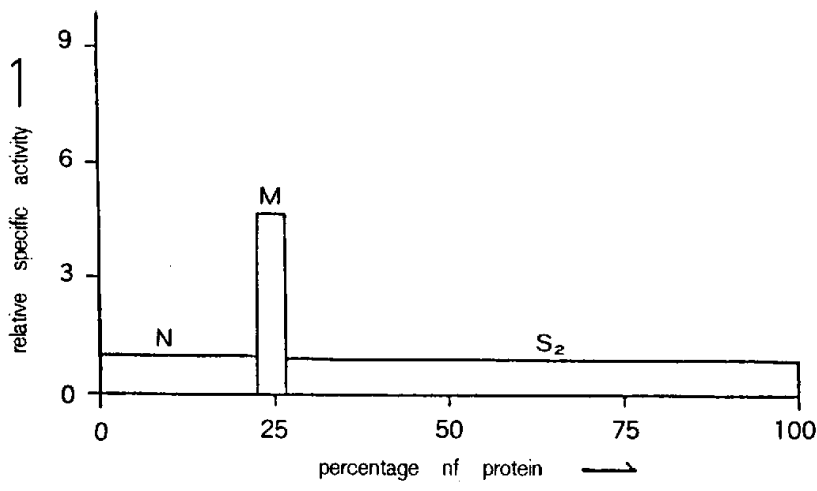

Fig. 8 Relative specific activity of succinate dehydrogenase in subcellular fractions prepared by Polytron treatment for $5 \mathrm{~min}$.

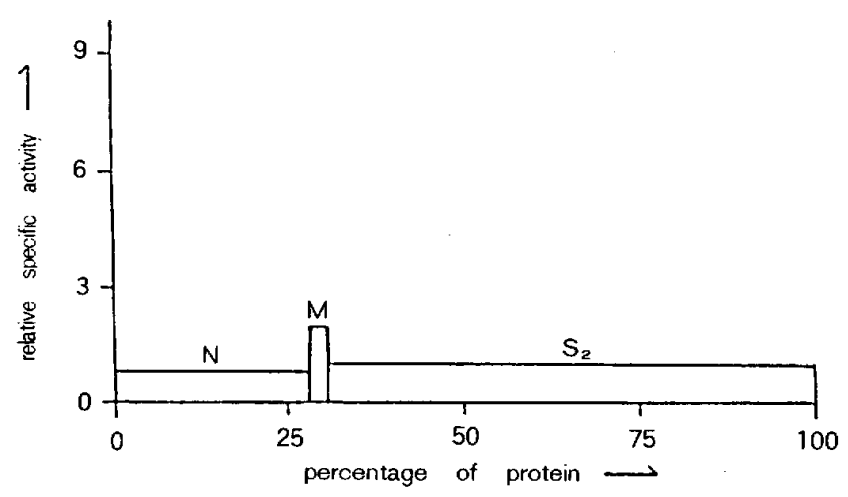

Fig. 9 Relative specific activity of succinate dehydrogenase in subcellular fractions prepared by Polytron treatment for $10 \mathrm{~min}$.

コンドリア画分の相対比活性は減少している。

II . ポリトロンホモジネート操作時間と酸素消費量

ポリトロン操作時間 1 分, 2 分, 5 分にて調製したる トコンドリア画分について, 酸素消費量を測定しその值 を Table 2 に表わした．操作時間 1 分， 2 分， 5 分で調 製したミトコンドリアの溶存酸素の変動を 1 分当り 6 mmの速度で記録した測定記録を Figs. 10〜12 に示し た。操作時間 1 分での 5 例の平均酸素消費量は内在呼吸 で $1.50 \mathrm{n}$ atoms $/ \mathrm{min} . / \mathrm{mg}$ protein であり，コハク酸 添加によりわずかに増加し，さらに ADP を加えるとや や増加傾向示した．操作時間 2 分と 5 分では内在呼吸に コハク酸を源加すると酸素消費量はともに増加する。し かしその増加量は操作時間 5 分が 2 分に比べて 1.4 倍と 多く, ADPを加えると抑制傾向を示した (Table 2).

III .コラーゲン分解酵素濃度とコハク酸脱水素酵素の 比活性

歯肉組織を破砕し呼吸調節能を有するミトコンドリア を調製するにはポリトロンの機械的作用のみでは不十分 と考え, コラーゲン分解能を有するコラーゲン分解酵素 の酵素作用を利用した。ポりトロン操作時間はコラーゲ ン分解醉素による歯肉コラーゲンの分解を期待し次の時 間を選んだ. ミトコンドリア画分の比活性值が最も高か ったポリトロン操作時閒 2 分で行うよりもコハク酸脱水 素酵素の各画分の比活性と調製ミトコンドリア画分の酸 素消費量から瞇肉の破砕は十分ではないが脱共役の少な いと考えられる操作時閒 1 分間にてポリトロンホモジネ 一ト走行った。 $0.04 \% ， 0.2 \% ， 1 \%$ と $5 \%$ 濃度のコラ 一ダン分解酵素を歯肉ミンス状細片とインキュベーショ ンしたのち分画した核画分, ミトコンドリア画分と上清 $\left(\mathbf{S}_{2}\right)$ 画分のコ八ク酸脱水素醳素比活性を Table 3 に示 
Table 2 Respiration of gingival mitochondria.

\begin{tabular}{c|c|c|c}
\hline $\begin{array}{c}\text { time of } \\
\begin{array}{c}\text { Polytron } \\
\text { homogenate } \\
\text { (min.) }\end{array}\end{array}$ & \multicolumn{3}{|c}{$\begin{array}{c}\text { oxygen consumption } \\
\text { (n atoms } / \mathrm{min} . / \mathrm{mg} \\
\text { protein) }\end{array}$} \\
\cline { 2 - 4 } & $\begin{array}{l}\text { endogenous } \\
\text { respiration }\end{array}$ & $\begin{array}{l}\text { succinate } \\
\text { respiration }\end{array}$ & $\begin{array}{l}\text { ADP-sti- } \\
\text { mulated } \\
\text { succinate } \\
\text { respiration }\end{array}$ \\
\hline 1 & $1.50 \pm 0.38$ & $1.65 \pm 0.49$ & $1.81 \pm 0.52$ \\
2 & $1.34 \pm 0.31$ & $1.80 \pm 0.28$ & $1.73 \pm 0.41$ \\
5 & $1.46 \pm 0.49$ & $1.98 \pm 0.37$ & $1.89 \pm 0.45$ \\
\hline
\end{tabular}

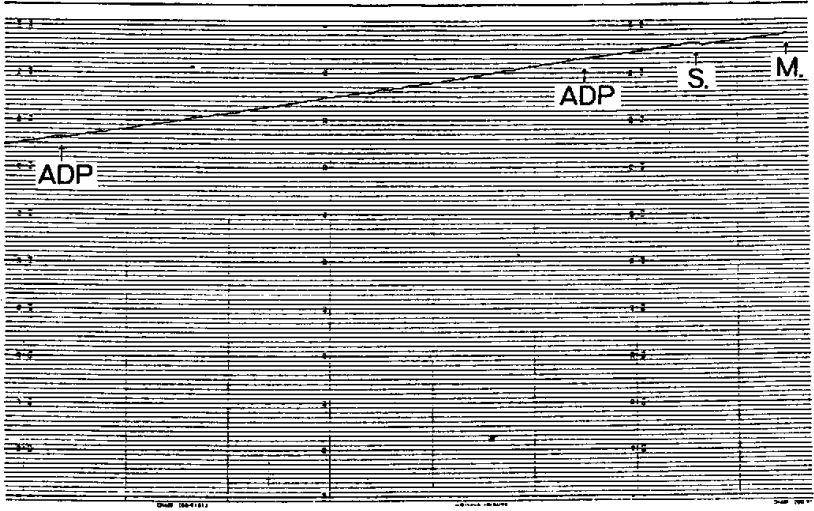

Fig. 10 Polarographic tracing of mitochondrial respiration (Polytron $1 \mathrm{~min}$.).

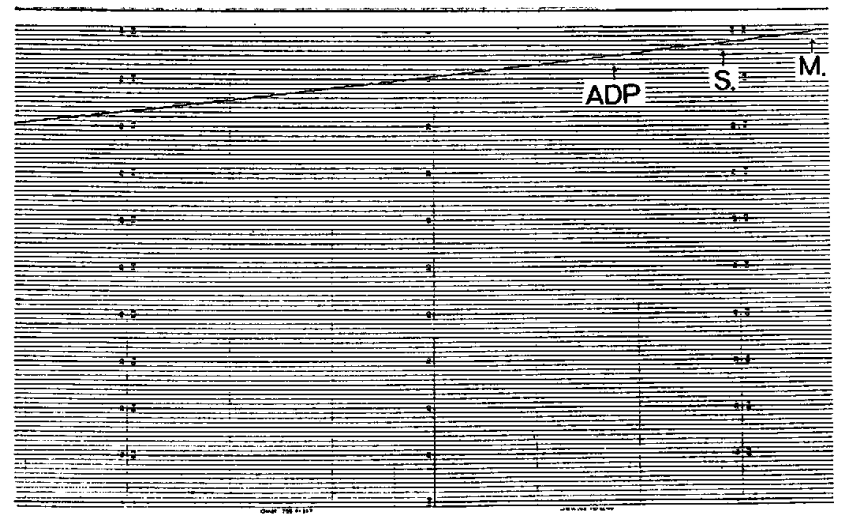

Fig. 11 Polarographic tracing of mitochondrial respiration (Polytron $2 \mathrm{~min}$.).

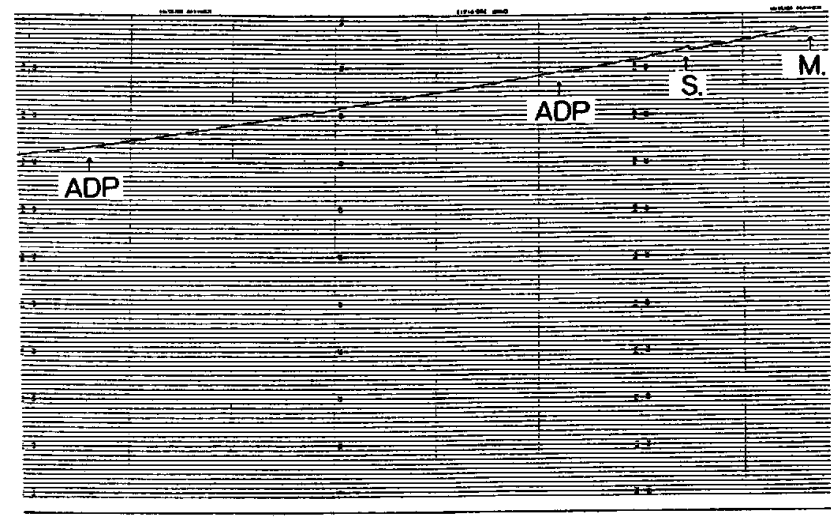

Fig. 12 Polarographic tracing of mitochondrial respiration (Polytron $5 \mathrm{~min}$.).

Table 3 Specific activity of succinate dehydrogenase in subcellular fractions prepared with collagenase.

\begin{tabular}{c|c|c|c}
\hline \multirow{2}{*}{$\begin{array}{c}\text { amount of } \\
\text { collagenase }\end{array}$} & $\begin{array}{c}\mid 3 \\
\text { nuclear } \\
\text { fraction }\end{array}$ & $\begin{array}{l}\text { mitochon. } \\
\text { fraction }\end{array}$ & $\begin{array}{c}\text { supernatant } \\
\left(\mathrm{S}_{2}\right)\end{array}$ \\
\hline control & $1.69 \pm 0.66$ & $1.39 \pm 0.47$ & $0.56 \pm 0.14$ \\
0.04 & $0.75 \pm 0.12$ & $1.34 \pm 0.29$ & $1.07 \pm 0.21$ \\
0.2 & $0.25 \pm 0.07$ & $2.00 \pm 0.43$ & $1.17 \pm 0.13$ \\
1 & $0.93 \pm 0.27$ & $8.71 \pm 2.56$ & $0.49 \pm 0.08$ \\
5 & $0.35 \pm 0.06$ & $0.69 \pm 0.23$ & $1.27 \pm 0.28$ \\
\hline \multicolumn{3}{|c}{$\mu \mathrm{mol} / \mathrm{min} \cdot / \mathrm{mg}$ protein }
\end{tabular}

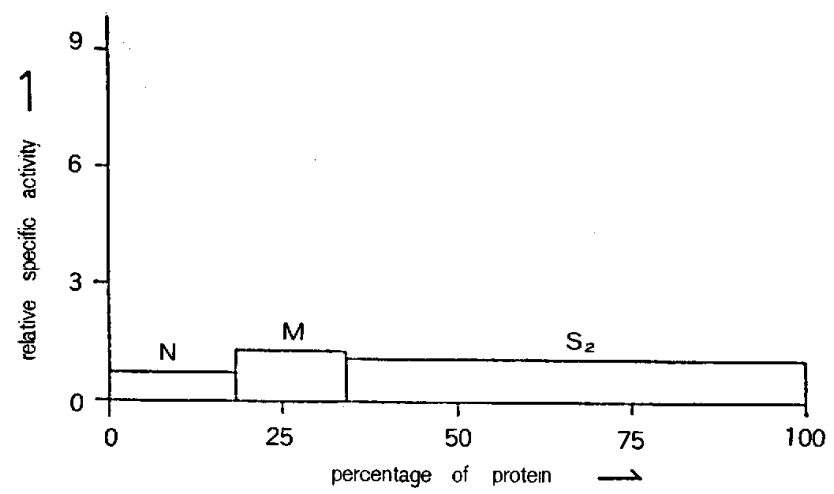

Fig. 13 Relative specific activity of succinate dehydrogenase in subcellular fractions prepared with $0.04 \%$ collagenase. 


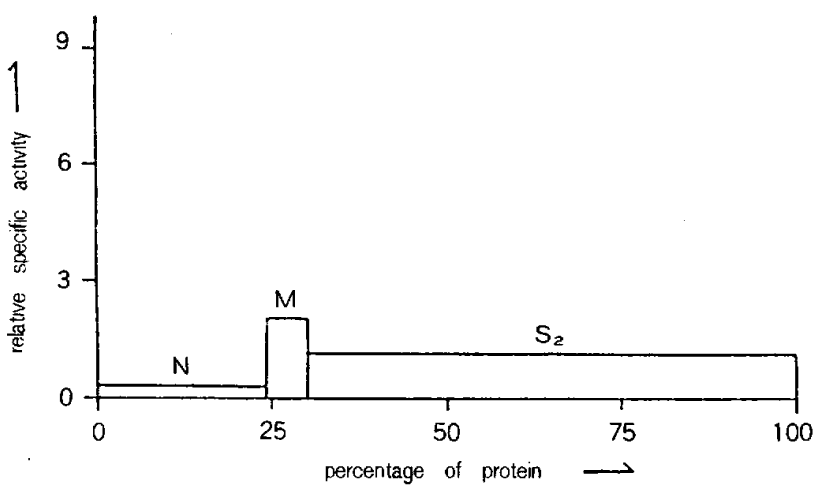

Fig. 14 Relative specific activity of succinate dehydrogenase in subcellular fractions prepared with $0.2 \%$ collagenase.

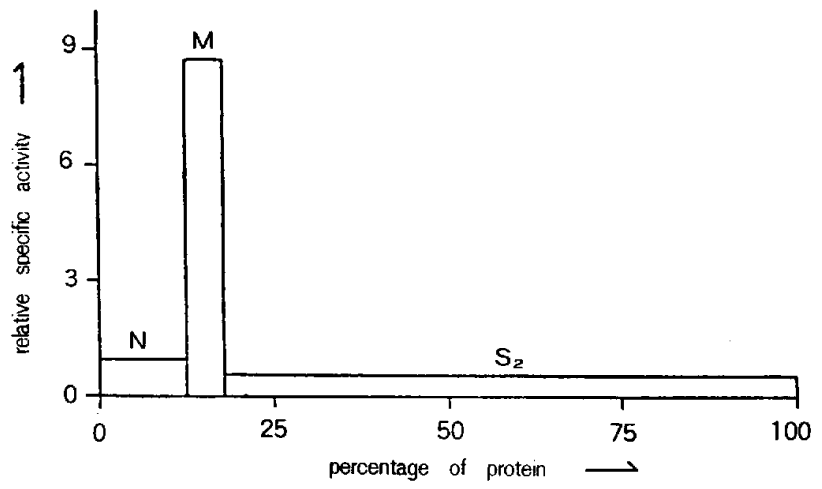

Fig. 15 Relative specific activity of succinate dehydrogenase in subcellular fractions prepared with $1 \%$ collagenase.

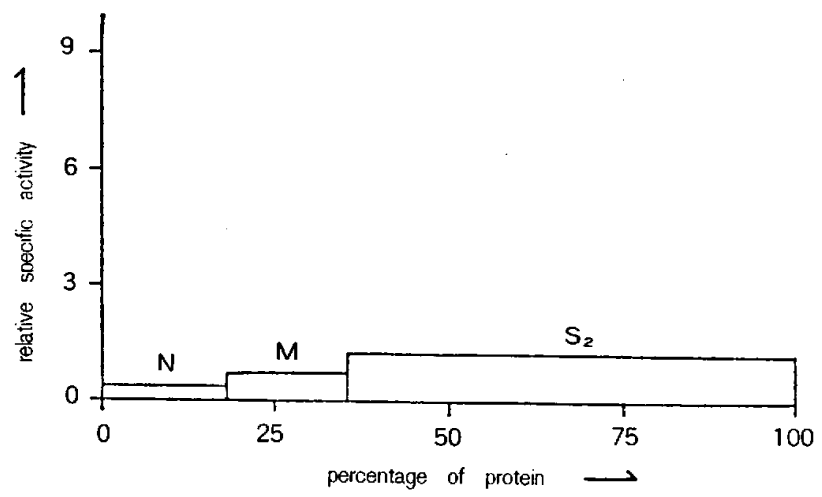

Fig. 16 Relative specific activity of succinate dehydrogenase in subcellular fractions prepared with $5 \%$ collagenase.
した.

$0.04 \%$ 濃度コラーゲン分解酵素にて調製した核画分の 比活性と相対比活性は対照に比し低い值となっている. しかし上清 $\left(\mathrm{S}_{2}\right)$ 画分は逆に比活性と相対比活性は高く なっているが，ミトコンドリア画分の比活性值は対照と ほぼ同じ值である(Table 3，Fig. 13). 、トコンドり ア画分のコハク 酸脱水素酵䒺の比活性は $0.2 \% ， 1 \%$ と $5 \%$ 濃度で比較すると $1 \%$ 濃度の比活性は $0.2 \%$ 濃度の 4 倍, $5 \%$ 濃度の 10 倍以上で, 最も高い比活性值が得ら れ，相対比活性も最大であり上清 $\left(\mathbf{S}_{2}\right)$ 画分と核画分の 相対比活性はともに最少であった。 $5 \%$ 濃度ではその比 活性值は大きく低下した (Figs. 14〜16).

N.コラーゲン分解醉素浱度と酸素消費量

歯肉ミンス状細片に0.04\%，0.2\%，1\%と $5 \%$ \% 4 種類の濃度の異なるコラーゲン分解酵素で処理しミトコ ンドリア画分を調製した。ミトコンドリア画分の内在呼 吸，コハク酸および ADP を加えた時の酸素消費量の変 化を Table 4 亿示した。

$0.04 \%$ 濃度で調製したミトコンドリア画分の酸素消費 量は内在呼吸で $2.35 \mathrm{n}$ atoms $/ \mathrm{min} . / \mathrm{mg}$ protein で あるが，コハク酸を添加すると 1.3 倍に増加し, さらに ADP を添加すると酸素消費量は抑制された。0.2\%調製 そトコンドリア画分のコハク酸添加呼吸量は内在呼吸の 1.9倍に増加し，さらに ADP を加えるとわずかではあ るが酸素消費量の増加がみられた。 $1 \%$ 濃度で調製した ものではコハク酸を添加することにより内在呼吸の 4.2 倍に酸素消費量は増加し，ADP を加えるとさらに35\% 増加した５\%濃度で調製したものでは酸素消費量はコ ハク酸添加で内在呼吸の2.7倍に増加し，ADPの添加で さらに20\%の増加が認められた（Table 4).

Table 4 Respiration of gingival mitochondria.

\begin{tabular}{c|c|c|c}
\hline \multirow{2}{*}{$\begin{array}{c}\text { amount of } \\
\text { collagenase }\end{array}$} & \multicolumn{3}{|c}{$\begin{array}{c}\text { oxygen consumption } \\
\text { atoms/min./mg protein })\end{array}$} \\
\cline { 2 - 4 } & $\begin{array}{l}\text { endogenous } \\
\text { respiration }\end{array}$ & $\begin{array}{l}\text { succinate } \\
\text { respiration }\end{array}$ & $\begin{array}{l}\text { ADP-sti- } \\
\text { mulated } \\
\text { succinate } \\
\text { respiration }\end{array}$ \\
\hline control & $1.50 \pm 0.38$ & $1.65 \pm 0.49$ & $1.81 \pm 0.52$ \\
0.04 & $2.35 \pm 0.75$ & $3.03 \pm 0.86$ & $2.07 \pm 0.34$ \\
0.2 & $1.34 \pm 0.45$ & $2.52 \pm 0.43$ & $2.60 \pm 0.44$ \\
1 & $1.19 \pm 0.23$ & $4.96 \pm 1.21$ & $6.80 \pm 1.75$ \\
5 & $0.87 \pm 0.35$ & $2.34 \pm 0.48$ & $2.83 \pm 0.65$ \\
\hline
\end{tabular}


コラーゲン分解醏素濃度別に調製した溶存酸素消費量 の変化の測定記録を 1 例ずつ $0.04 \%, 0.2 \%, 1 \%$ と 5 \%をそれぞれ Figs. 17〜20 に示した. 0.04\%，0.2\%調 製ミトコンドリアの例ではコ八ク酸添加による酸素消費 量の増加がみられるが，ADP 添加後は酸素消費量は抑 制されている.

$1 \%$ 調製 ミトコンドリアはコ八ク酸存在下で ADP 添 加後約 6 分で酸素消費量の減少が始まった。一定時間観 察したのち再び ADP の添加により再度酸素消費量は増 加した． $5 \%$ 調製乏トコンドリアの酸素消費量は，1\% 調製ミトコンドリアに比し少量ではあるが ADP 添加時 の酸素消費量は増加し約12分後に酸素消費量の減少が 珰められ，ADP のリン酸化に 2 倍の時間を要している (Figs.19, 20).

$\mathrm{V}$ ．歯肉 ミトコンドリアの呼吸調節

Chance ら $(1955)^{20}$ の分類した state 3 は呼吸基質 存在下において ADP を添加することにより酸素消費量

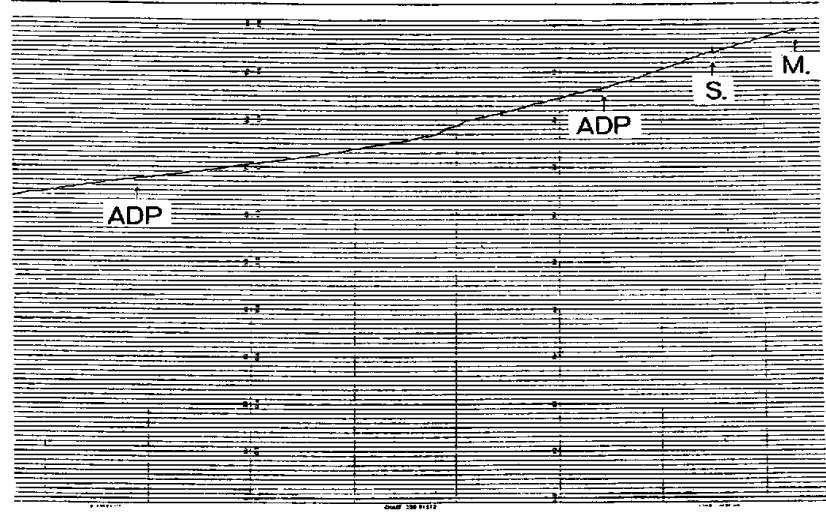

Fig. 17 Polarographic tracing of mitochondrial respiration $(0.04 \%$ collagenase $)$.

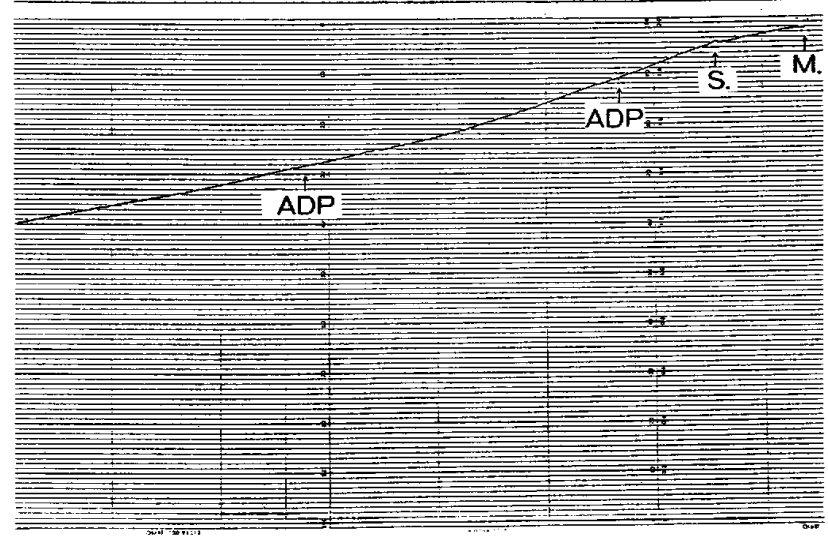

Fig. 18 Polarographic tracing of mitochondrial respiration $(0.2 \%$ collagenase $)$.

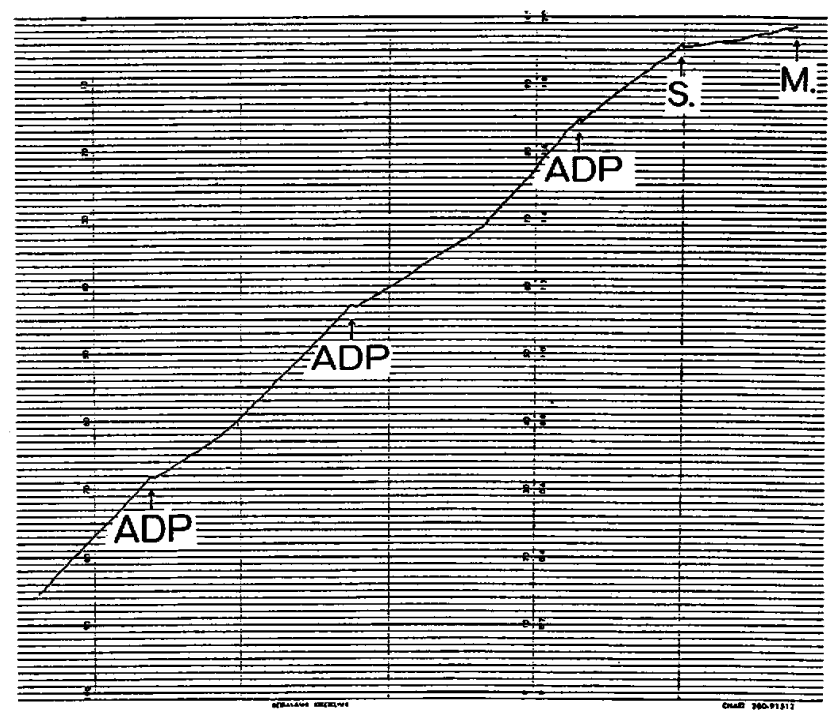

Fig. 19 Polarographic tracing of mitochondrial respiration ( $1 \%$ collagenase).

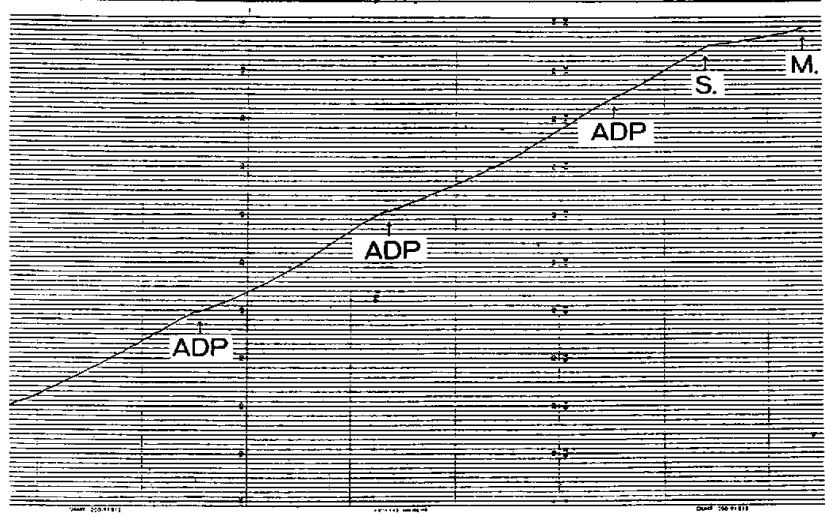

Fig. 20 Polarographic tracing of mitochondrial respiration ( $5 \%$ collagenase).

が増加している状態である．その後呼吸基質存在下で ADP がすべて ATP に変換され酸素消費量が減少した 状態が state 4 である. 歯肉から調製したミトコンドリ アにおいてはての state 3 と state 4 はいまだ報告さ れていない. state 3 と state 4 の酸素消費速度の比が 呼吸調節率であり， state 3 の状態で消費された ADP の分子数と酸素原子数との比が $\mathrm{ADP} / \mathrm{O}$ 比でいずれも ミトコンドリアの呼吸機能を表わす． $1 \%$ と $5 \%$ 濃度コ ラーゲン分解醭素を Hanks の溶液中でインキュベーシ ョンすることによりコラーゲン分解醏素を作用させポリ トロンにて 1 分間ホモジネートし分画後そトコンドリア を調製した。そのイヌ歯肉之トコンドリアに呼吸調節が みられ，四吸活性は Table 5 に示しているように state 4 で酸素消費量は大きく減少している. 
$5 \%$ 調製 ミトコンドリアでは ADP/O 比 1.35 , 呼吸 調製率 $1.65 ， 1 \%$ 調製々トコンドリアでは ADP $/ O$ 比 1.42 , 呼吸調節率 1.76 となり，1\%コラーゲン分解酵素 を用いて調製したミトコンドリアは $5 \%$ で調製したもの に比較して損傷の少ない呼吸調節率のよいミトコンドリ アであることが判明した。

Table 5 Respiratory function of gingival mitochondria.

\begin{tabular}{c|c|c|c|c}
\hline \hline $\begin{array}{l}\text { amount of } \\
\text { collagenase }\end{array}$ & \multicolumn{2}{|l|}{$\begin{array}{l}\text { oxygen consumption } \\
\text { (n atoms/min./mg } \\
\text { protein) }\end{array}$} & $\begin{array}{c}\text { ADP/O } \\
\text { ratio }\end{array}$ & $\begin{array}{l}\text { respir- } \\
\text { atory } \\
\text { control } \\
\text { ratio }\end{array}$ \\
\hline \begin{tabular}{c|c|c|c|} 
state 3 & tate 4
\end{tabular} & & - & - \\
0.04 & $2.07 \pm 0.34$ & - & - & - \\
1 & $2.60 \pm 0.44$ & - & - & 1.76 \\
5 & $6.80 \pm 1.75$ & $3.86 \pm 1.03$ & 1.42 & 1.65 \\
\hline
\end{tabular}

\section{考察}

粜肉乏トコンドりアのエネルギー代謝に抢ける酸化的 リン酸化や電子伝達を研究することは，米肉の損傷や菌 周病における雨肉組織の反応を理解するために重要であ るが，菌肉ミトコンドリアの酸化的リン酸化や電子伝達 を乎吸調節によって研究された報告はみられない，歯肉 の乎吸に関する研究は Glickman ら $(1949)^{25)}$ がヒト 正常歯肉と炎症歯肉の酸素消費量を発表している．その 後木下 $(1959)^{15}{ }^{15}$ も柬周病と歯肉の組織呼吸の関連性に ついて研究し，蒾肉をホモジートすると酸素消費量は 減少するが，NAD やチトクロームCを添加すれば著し く酸素消費量が増加することを明らかにしている．また 鈴木 $(1963)^{26}$ もラット歯肉ホモジートの酸素消費量 を増加させるにはコ八ク酸や ATP が有効であると述べ ている。乙れらとその後の報告は歯肉スライスや蔝肉ホ モジネートを用いて呼吸基質の有無における酸素消費量 の相違や正常䨑肉と炎症歯肉の酸素消費量を比較したも のばかりである。

酸素消費量の測定は反応液中の酸素濃度々気相中の酸 素分圧の変化を測定するWarburg 検圧法を用いて研究 が行われている。この方法はその平衡に時間を要し時間 的なずれの中で酸素消費量值を測定するため，連続的な 測定記録を得られず酸素の微量測定や呼吸活性の詳細 を知るには難点がある．乙の点に注目した田中（1954） 27) は Warburg 法の上うに容器を振渴する必要もなく
原理を異にする Oxigraph にて浴存酸素消費量の測定 を試みている，ての方法は白金と塩化銀の両電極間に 2.5 秒間加電圧し，その時の溶存酸素量を 10 秒毎に連続 写真撮影するととにより，断続的な連続測定の記録を可 能にしている。

本研究で酸素消費量の测定に用いた酸素電極法は Chance ら $(1955)^{20 \prime}$ がミトコンドリアの呼吸を測定し て広く知られるようになった。原理はポーラログラフ法 の一応用であり，溶存物 (酸素) が電極で酸化還元を受 けることで生じる電解電流の量によって溶質を定量する ものである．初期には静止した状態で白金電極を使用し ていたが, その後, 上下振動する電極や, 電極を静止さ せ容器内溶液を回転させる方法を用い酸素濃度の变化を 連続的に記録させたが，開放型であり電極も露出したま まであったため外部からの酸素の侵入と電極の污染は防 止できなかった．そこで，Hagihara $(1961)^{28)}$ は電極 端をポリエチレン膜やテフロン膜で被うととにより電極 の污染を防ぎ，さらに外部からの酸素の侵入を防止する 密閉型反応容器を考案した。これらの一連の改良により 酸素電極法は安定性と応答性に優れ，連続的測定記録が 得られる方法となった。

歯肉の酸素消費量については，茵肉と他の臟器と比較 した報告はないが，酸化還元䤃素活性を比較した Eichel ら (1957）17 の報告がある. その活性は肝の1/10であり， 歯髄よりも低く網膜や脈絡膜と同程度に低いと述へてお り，ての点について Theodore ら (1968) ${ }^{29}$ ' の歯髄酸素 消費量と栢ら $(1983)^{30}{ }^{\prime}$ の雬肉酸素消費量を比較してみ ても䨑肉の酸素消費量は歯髄より低いようである。また 構造タンパクであるコラーゲンを主成分とする崡肉結合 組織の酸素消費量は雨肉上皮組織の $1 / 3$ であり，結合組織 が大部分を占める菌肉組織内のミトコンドリア量は他の 臟器に比べて少ないてとが推察される31,321. したがっ て, 䨑肉組織呼吸活性が低く, 肝臓や心臟のように試料 を多量に採取することが困難である雪肉を試料として呼 吸活性を測定するには酸素電極装置はもっとも適してい ると考光今回の実験に使用した. Palmer ら (1977) ${ }^{33)}$ はポリトロンとタンパク分解酵素を用いミトコンドリア を調製し，機能的にも形態的にも良質のミトコンドリア を得ている、したがって，䨑肉よりミトコンドリアを調 製するにあたり，肝や心筋で行っている機械的破研手段 であるポりトロンを使用してコラーゲンの破砕を試み た、ポリトロンホモジネートで調製したミトコンドリア は操作時間 2 分以上でコハク酸脱水素醉素の比活性は高 くなり, ポリトロン操作時間 1 分, 2 分, 5 分の内在呼 
吸量はほぼ同じであるもののコハク酸添加による呼吸量 が増加している． 野田(1975) ${ }^{34)}$ が紫外線をミトコンド リアに照射して脱共役させた実験では照射紫外線量が多 くなると内在呼吸量に変化はないが，コハク酸添加呼吸 量が増え酸化的りン酸化反応の脱共役が大きくなると述 べている。この野田 $(1975)^{34)}$ の報告から推察すると著 者のポリトロン操作時間が 1 分, 2 分, 5 分と増加する につれて脱共役が大きくなり，ミトコンドリアの損傷が 多くなると思われる。

Rosset ら (1972) ${ }^{35)}$ はウシ付着歯肉ホモジネートを 用いた実験で内在呼吸にコハク酸を加えると呼吸量は 5 倍に増加し, 内在呼吸に ADP を添加すれば四吸量は同 しく 5 倍になり，また,コハク酸とADP を同時に加える と内在呼吸量の 6 倍になったと報告している。乙れは木 下 (1959) 15)の “dilution effect”により内在呼吸が大 幅に減少したと考えると，呼吸基質のコハク酸か ADP を補給することにより酸素消費量が回復したと考えられ る、コハク酸を添加した後にさらにADP を加えること により酸素消費量の值がいくぶん高いととは, 本実験の ポリトロン操作 1 分のみと $0.2 \%$ コラーゲン分解酵素で 調整した 2 種類のミトコンドリアにおいて内在呼吸の酸 素消費量がコハク酸の添加で増加し，その後の ADP 添 加でさらにやや増加している事実とよく似ている。また Rosset ら $(1972)^{35}$ はウシ歯肉よりミトコンドリア画 分を調製し、ミトコンドリア画分に上清を加えコハク酸 を添加すると内在呼吸加量が增し，ミトコンドリア画分 に上清およびコハク酸を加えた乎吸に ADPやNAD を添加すれば ADP で50\%，NAD で60\%呼吸を阻害す ることを示しており，本実験のポリトロン操作時間 2

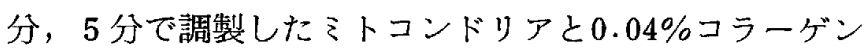
分解酻素で調製したミトコンドリアではコハク酸添加に より酸素消費量は增加するが，ADP 添加で抑制される ととと一致する．その理由について彼らは呼吸調節は歯 肉乏トコンドリアに存在するが脱共役しているか，もし くは呼吸が進行するにしたがって代謝活性が遅くなる内 在調節機構が細胞内に存在しているのではないかと推察 しているが，著者はミトコンドリアの損傷が大きいこと によるものと考えている。

Ernster (1967) ${ }^{36}$ ) は骨格筋をポリトロンにて 1〜2 分間ホモジネートしミトコンドリアを調製して扔り，ポ リトロン操作時間 2 分以上では曾肉ミトコンドリア自身 の損傷も大きいととを考慮し，歯肉ホモジネートが不十 分であるがミトコンドリアの損傷の少ないと考えられる 操作時間 1 分でコラーゲン分解醳素を用いて実験を行う
こととした。

一般に蒾肉コラーゲンを破砕する手段としてポリトロ ンなどの機械的手段以外に考えると,コラーゲンを $60^{\circ} \mathrm{C}$ 以上の熱で刺激するととによりコラーゲンの水素架橋を 壊すか酸で変性させ, 三重ラセン構造を変性させてコラ 一ゲン分解酵素以外のタンパク分解醭素で消化するてと が出来る．しかししの熱や酸を用いる方法は損傷の少な いミトコンドリアを得るには適当でないと考えコラーゲ ン分解醅素を利用することにした、コラーゲン分解醅 素として Bacteroides melaninogenicus ${ }^{371}$ 由来の䣼素 は30万のコラーゲン分子を 10 万と 20 万に分断するが， Clostidium hystoryticum 由来のコラーゲン分解䤏素 は小さなペプタイドに直接分断し，かつ市販されてお り，ての酵素を使用することにした，乙の酵素の作用時 はCa\#存在下が望ましいだめ, Ca+ の存在する Hanks の溶液中にてィンキュベーションをした。萩原ら (1972) 38) のタンパク 分解醉素法では心筋切片にタンパク分解 酥素を20分間作用させたのちテフロンにてホモジネート し，さらに20分間使用させている. Ogura ら(1979) ${ }^{91}$ は室温にて20分間タンパク分解䤃素を作用させ呼吸調節 率4.0という共役機能のよい心筋 ミトコンドリアを調製 している.一方，コラーゲン分解酔素を利用して組織を 破研したものとしては Mehard (1967) ${ }^{39)}$ がマウス乳 腺からミトコンドりアを調製するため，0.1\%コラーゲ ン分解酵素を $37^{\circ} \mathrm{C}$ にて60分間作用させており, Sinden ら $(1979)^{40)}$ も來肉より線維芽細胞を抽出するため0.05 \%コラーゲン分解酵素を Hanks の溶液中にて60分間作 用させている。

著者は，乙れらの報告を参考にしてコラーゲン分解酵 素を効果的に作用させるとともにミトコンドリアへの影 響を配慮し $20^{\circ} \mathrm{C}$ にて20分間作用させた.コラーゲン分 解酵素濃度は $0.04 \%$ からその濃度を上昇させた。

著者の実験結果は， $1 \%$ と $5 \%$ コラーゲン分解酵素を 作用させポりトロン操作時間 1 分間にて調製したるトコ ンドリア画分の呼吸活性測定で Chance ら (1955) 201 の分類による state $1 ， 2 ， 3 ， 4$ を確認できる. しか し，本実験では酸化的りン酸化や共役状態と関連のある state 3 , state 4 を中心検索するため, state 表わ す順序は肺，心筋等 ミトコンドリアの多くの研究と同じ ように state 1 , state 3 , state 4 の順で表わした。 $5 \%$ $\%$ コーゲン分解醭素を作用させたものについても呼 吸調節が確認できたが，ADP/O 比，呼吸調節率とも 1 \%コラーゲン分解醉素を作用させたものに比し低い值で あった。 $5 \%$ という高濃度のコラーゲン分解䤃素作用が 
ミトコンドリアへ影響があるのか，他の因子によるもの か不明である、コラーゲン分解酵素 $1 \%$, ポリトロン操 作 1 分で調製したミトコンドリアでは内在呼吸は 1.19 $\mathrm{n}$ atoms $/ \mathrm{min} . / \mathrm{mg}$ protein で $2 \mathrm{mM}$ コハク酸を加え ると 4.2 倍に呼吸量は壃加し, さらに $100 \mu \mathrm{M} \mathrm{ADP}$ 添加 では内在呼吸の5.7倍となっている。

Tyler ら $(1967)^{41)}$ が測定した心筋 ミトコンドリア の呼吸活性は state 3 で $253 \mathrm{n}$ atoms $/ \mathrm{min} . / \mathrm{mg}$ protein, state 4 で 79.1, $\mathrm{ADP} / \mathrm{O}$ 比 1.8 , 呼吸調節 率 3.2 であり，一方，野田 $(1975)^{34 \prime}$ の朋乏トコンドリ アでは, state 3 が 52.7 , state 4 12.6, ADP/O 比 1.8, 呼吸調節率 3.8 と報告されている。 また，Albert ら $(1973)^{42}$ がヒト線維牙細胞を培養したのちミトコン ドリアを調製しその呼吸活性を測定した結果では state 3 で22.4, state 4 が $6.0, \mathrm{ADP} / \mathrm{O}$ 比 1.7 , 呼吸調節率 3.8 となている。呼吸基質がコハク酸の場合 $\mathrm{ADP} / \mathrm{O}$ 比が1.7〜 1.8 ，呼吸調節率が 3 〜 であれば良質な之卜 コンドリアと言われており，乙れらの測定結果は長い研 究の間分画方法が改良され優れたものである。呼吸活性 が肝の10〜15\%と言われる米肉から著者らが調製したる トコンドリアの呼吸活性 1.42 と呼吸調節率1.76はこれか らさらに改良されていかなくてはならない。

\section{結論}

イヌ雪肉より呼吸調節能を有する歯肉之トコンドリア の調製を試みた。䨑肉にはコラーダンが多いため，その 破砕にはポリトロンとコラーゲン分解酵素を用いて歯肉 を核画分，ミトコンドリア画分，上清 $\left(\mathrm{S}_{2}\right)$ 画分に分画 し，各画分のコハク酸脱水素酵素活性を測定した。ま
た，ミトコンドリア画分については酸素電極法にて呼吸 活狌を測定し，次の結論を得た。

1. 歯肉をポリトロンにて操作時間 0.5 分, 1 分, 1.5 分, 2 分, 5 分と 10 分にて調製したミトコンドリア画分 のコハク酸脱水素酵素比活性は操作時間 2 分間のものが 最も高かった。

2. ポリトロン操作時間 1 分, 2 分, 5 分間にて調製 したミトコンドリア画分の酸素消費量を測定したが，呼 吸調節はみられなかった。

3. $0.04 \% ， 0.2 \% ， 1 \% ， 5 \%$ コラゲン分解酵愫 とポリトロン操作時間 1 分間にて調製したミトコンドリ アのコハク酸脱水素醳素比活性は， $1 \%$ ラーゲン分解 酵素を作用させたものが最も高かった。

4.コラーゲン分解酵素で調製したミトコンドりア画 分の呼吸活性を測定したととろ，1\%と $5 \%$ 分解酵素で調製したミトコンドリアに呼吸調節がみられ た。

5. ADP $/ \mathrm{O}$ 比と呼吸調節率は $1 \%$ \%ラーゲン分解酵 素で調製したミトコンドリアが $5 \%$ のものより高い值で あった。

稿を終わるに臨み，本研究に終始御懇切なる御指導と 御校閲を賜った恩師柏 豪洋教授に深甚なる感謝の意を 表します。また，教室員諸兄に対し樑く感謝致します。

本論文の要旨は第27回秋季日本歯周病学会総会（昭和 59年，広島市）抢よび，第28回秋季日本歯周病学会総会 (昭和60年，名古屋市）に扔いて発表した。

\section{引用 文 献}

1) Hogeboom, G.H., Schneider, W.C. and Palade, G.E. : Cytochemical studies of mammalian tissues. I . Isolation of intact mitochondria from rat liver. Some biochemical properties of mitochondria and submicroscopic particulate material. J. Biol. Chem. 172:619-635, 1948 .

2 ) Schneider, W.C. : Intracellular distribution of enzymes. The oxidation of octanic acid by rat liver fractions. J. Biol. Chem. $176: 259-262,1948$.

3) Schneider, W.C. and Hogeboom, G.H.: Intracellular distribution of enzymes. V. Further studies on the distribution of cytochrome $\mathrm{c}$ in rat liver homogenates. $\mathrm{J}$. Biol. Chem. 183 : 123-128, 1950 .

4 ) VonKroff, R.W. : Metabolic characteristics of isolated rabitt heart mitochondria. J. Biol. Chem. 240:1351-1358, 1965. 
5) Takeru, I. and Ralph, M.J. : Effects of a nutritional deficiency of unsaturated fats on rat liver mitochondria. J. Biol. Chem. $239: 3201-3208,1964$.

6) Chance, B. and Hagihara, B. : Intracellular respiration. Phosphorylating and noinphosphorylating oxidation reactions. In : International congress of biochemistry. (ed. by Pregamon, P.). MacMillan. New York, 1963, 3-26.

7) Ozawa, K., Seta, K., Araki, H. and Handa, H. : The effect of ischemia on mitochondrial metabolism. J. Biochem: 61:512-514, 1967 .

8 ) Ozawa, K., Seta, K., Takeda, H., Aono, K., Handa, H. and Araki, C.: On the isolation of mitochondria with high respiratory control from rat brain. J. Biochem. 59:501-510, 1966 .

9) Ogura, R., Toyama, H., Nagata, O., Ono, T., Shimada, T. and Murakami, M.: Biochemical and scanning electron microscopic properties of mitochondria isolated from rat cardiac muscle. Kurume Med. J. $26: 51-56,1979$.

10) Glickman, I., Turesky, S. and Manhold, J. : The oxygen consumption of healing gingiva. J. Dent. Res. 29:429-435, 1950 .

11）川勝蜸作・森 昌彦：人の口腔歯肉粘膜上皮代謝の組織化学的, 細胞化学的研究. 口科誌 $7: 128 一 137$, 1958 .

12）錐型 勝：歯肉の生理的研究. 歯科医学 $20: 44-50 ， 1957$.

13）高田嘉定・森 昌彦：人粜肉の組織呼吸, 主として酸素消費量について. 日口外誌 6：412一416, 1957 .

14) Lehninger, A.L.: The mitochondrion molecular basis of structure and function Benjamin, New York, 1964, 40-91, 148-149.

15）木下四郎：雬肉の呼吸に関する研究。口病誌 $26: 99-107,1959$.

16) Person, P. and Fine, A. : Reversible inhibition of beef heart cytochrome c oxidase by polyionic macromolecules. Science 132:43-44, 1960 .

17) Eichel, B. and Swanson, A.A. : Oxidative enzyme. I. Succinic dehydrogenase, DPN cytochrome c reductase, cytochrome oxidase and catalase in oral, liver and bran cortex tissues.

J. Dent. Res. 36:581-594, 1957 .

18）栢 承洋：柬肉コラーゲンに対する温熱的刺激の影響. 阪大歯誌 $17: 61-70,1972$.

19）原洋・香月 司・小野辰也・小倉良平・森園隆昭・村上正浩：Ultra-Turrax と Proteinase 併用に よる心筋ミトコンドリアの分離法. 久医会誌 $43: 333-340,1980$.

20) Chance, B. and Williams, G.R. : Respiratory enzymes in oxidative phosphorylation. Kinetics of oxygen utilization. J. Biol. Chem. 217:383-393, 1955.

21）萩原文二：酸素電極法による呼吸测定．蛋白䢙核酸酵素 $10 ： 1689-1702 ， 1965$.

22) Estabrook, R.W. : Mitochondrial respiratory control and the polarographic measurement of ADP : O rations. In : Oxidation and phosphorylation (ed. by Estabrook, R.W. and Pullman, M.E.). Academic Press, New York, 1967, 41-47.

23) Veeger, C.D., Vartanian, D.V. and Zeylemaker, W.P. : Spectrophotometric method with $K_{3}$ $\mathrm{Fe}(\mathrm{CN})_{6}$. In : Citric and cycle (ed. by Lowenstein, J.M.). Academic Press, New York, $1969,81-84$.

24) Lowry, O.H., Rosebrough, N.J., Far, A.L. and Randall, R.J. : Protein measurement with folin phenol reagent. J. Biol. Chem. 193:265-275, 1951 .

25) Glickman, I., Turesky, S. and Hill, R. : Determination of oxygen consumption in normal and inflamed human gingiva using the Warburg manometric technic. J. Dent. Res. 28 : $83-94,1949$. 


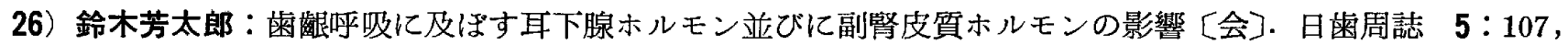
1963.

27）田中 明：雬肉の組織呼吸, 酸素消費量について.日口外誌 $4: 293-299,1954$.

28) Hagihara, B. : Techniques for the application of polarography to mitochondrial respiration. Biochim. Biophys Acta. $46: 134-142,1961$.

29) Theodore, C.M. and Alton, K.F. : Effects of heart on oxygen consumption in bovine dental pulp. J. Dent. Res. $47: 798-800,1968$.

30）栢 家洋・原賀義昭・今村哲也・春岡龍男・上田雄造・秋岡文吾・比嘉宗安・西浦利博・大田康男：イヌ歯 肉酸素消費量に関する研究一酸素電極法を用いて一。日歯周誌 $25: 350-355,1983$.

31) Derbyshire, J.C. and Mankodi, S.M. : Gingival keratinization with hand and electric toothbrushes. A cytological comparison. J. Am. Dent. Assoc. 68:255-259, 1964.

32) Krikos, G.A. : Histochemical studies of the periodontal ligament in lathyritic rats. Arch. Oral Biol. $9: 415-422,1964$.

33) Palmer, J.W., Tandler, B. and Hoppel, C.L. : Biochemical properties of subsarcolemmal and interfibrillar mitochondria isolated from rat cardlac. J. Biol. Chem. $252: 8731-8739,1977$.

34）野田和良：ミトコンドリア呼吸系に及ぼす紫外線照射の影響. 久医会誌 $38: 879-895,1975$.

35) Rosett, T., Gangarosa, L.P., Ashbridge, E.L., Belsky, A., Derenzo, G., Elder, H., Pollack, R.L., Sacco, U. and Tan, Y. : Respiration of homogenates and crude mitochondrial fractions of bovine attached gingiva. Arch. Oral Bial. 17:1543-1550, 1972 .

36) Ernster, L. : Skeletal muscle mitochondria. In : Oxidation and phosphorylation (eds. by Estabrook, R.W. and Pullman, M.E.). Academic Press, New York, 1967, 86-94.

37) Gibbons, R.I. and McDonald, J.B. : Degradation of collagenous substrates by bacteroides melaninogenicus. J. Bacteriol. 81:614-621, 1961 .

38）萩原文二・曽根 旉 史：細胞分画法. (佐藤 了・他編). 岩波書店，東京，1972，141-148.

39) Mehard, C.W. : Isolation of mitochondria from mouse mammary gland. In:Oxidation and phosphorylation (eds. by Estabrook, R.W. and Pullman, M.E.). Academlc Press, New York, 1967, 305-310.

40) Sinden, P.R.V. and Walker, D.M. : Inflammatory cells extracted from chronically inflamed gingiva. J. Periodont. Res. $14: 467-474,1979$.

41) Tyler, D.D. and Gonze, J. : The preparation of heart mitochondria from laboratory animals. In : Oxidation and phosphorylation (eds. by Estabrook, R.W. and Pullman, M.E.). Academic Press, New York, 1967, 75-78.

42) Albert, J.T.M. and Donald, A.P. : Oxidative phosphorylation in mitochondria isolated from human fibroblasts. Biochim. Biophys Acta. 292:73-77, 1973. 